\section{TREATMENT OF PREMATURITY*}

\author{
ROOD TAYLOR, M.D., D.Sc. \\ ROCHESTER, MINN.
}

It is my purpose to present in this paper the method and the results of the treatment of premature infants in the University of Minnesota Hospital. The material studied includes sixty prematurely born infants, all being born at, or otherwise admitted to, the clinic from September, 1914, when the department of pediatrics assumed charge of the new-born infants' clinic, wintil the close of 1917 .

It is noteworthy that Litzenberg's ${ }^{1}$ report of the clicacy of the four-hour feeding interval for premature infants, the first report in American literature, came from the obstetric service of the same hospital. As Litzenberg states, he was led to adopt the long interval by observing its success in a premature baby that vomited whenever a shorter interval was tried. No less an authority than Czerny had previously recommended that the premature baby be given no more than six feedings in the twenty-four hours. Since Litzenberg's paper, another by Grulee" has appeared reporting success with, and advocating the use of, the four-hour feeding interval, stating that it tends to prevent overfeeding, to avoid vomiting, a serious complication, and to avoid disturbing the infant.

Our experience supports Grulee's summing up, and we see only one disadvantage of major importance inherent in the practice of four-hour feeding. This is that in certain homes where insufficient effort is made thoroughly to empty the breasts, they will be inadequately stimulated and the milk supply will suffer correspondingly.

The babies in this series were fed breast milk on the four-hour interval, with a few exceptions in the second month, no other food was used. Many of them were tube-fed for varying lengths of time, a procedure first employed by Tarnier, ${ }^{3}$ and later advocated by Rott $^{4}$ and by Langstein. ${ }^{5}$ The tube, a small, soft rubber catheter attached to a glass funnel, was passed by mouth and inserted about $15 \mathrm{~cm}$. No injury to the babies ever resulted. The tube feeding was continued until the babies were able to nurse or take the bottle successfully. The smaller babies, weighing $2,000 \mathrm{gm}$. and less, accomplished this, on the average, at the end of the first month. Only one required two months before being able to take the breast. Two thirds of the infants with a birth weight of more than $2,000 \mathrm{gm}$. took the breast successfully in the first week. Only three needed to be tube-fed in the third week.

Table 1 shows the birth weights of the babies who strvived and the day on which they began to take considerable nourishment directly from the breast. Nearly half these babies, however, required complemental feedings for a week or two longer, that is, they were weighed before and after nursing, and the deficiency was made up by tube or bottle. The breast

* From the Department of Pediatrics of the University of Minnesota, Dr. J. P. Sedgwick, professor and chief of the department.

* Read before the Section on Diseases of Children at the Sixty-Ninth Annual Session of the American Medical Association, Chicago, June, 1918.

1. Litzenberg, J. C.: Long Interval Feeding of Premature Infants, Am. Jour. Dis. Child., December, 1912, pp. 391-409.

2. Grulee, C. G.: Care and Feeding of Incubator Babies, Surg., Gynec. and Obst., 1915, 20, 234-239.

3. Tarnier, quoted by Budin, P.: The Nursling, Iondon, 1907 , p. 28. 4. Rott: Zur Ernährungstechnik früligeborener Säuglinge, Ztschr. f. Kinderh., 1912, 5, 134174.

5. Langstein, L.: Ernährung und Wachstum der Frühgeborenen, Derl. klin. Wchnschr., 1915, 5, 631-634. supply of the mothers was kept up by manual expression or pumping, many of them sending their milk in twice a day by messenger.

Feeding, as a rule, was begun on the second day, the initial amounts being usually from 15 to $30 \mathrm{gm}$. six times in twenty-four hours. Oberwarth, ${ }^{6}$ Birk $^{7}$ and $\operatorname{Ladd}^{8}$ have found the daily caloric need of the premature infant to be slightly in excess of 100 calories per kilogram. Salge ${ }^{9}$ and Budin $^{10}$ place the amount about 50 per cent. higher, while Czerny and Keller give figures that lie between the two. According to Birk, after the tenth day, the premature baby needs about one seventh of his body weight in breast milk daily. It would seem-and this was our experiencethat no average applies to the individual baby. The chief factor to be considered is that the baby's tolerance for food must not be overstepped. Vomiting (other than an occasional slight regurgitation when the tube is withdrawn) seems to be the first danger signal, and on numerous occasions the baby's ration was temporarily reduced when this appeared. Certainly one should not wait for other evidences of overfeeding, such as diarrhea or irregular temperature.

TABLE 1.-BIRTH WEIGHT, CONTROL OF TFMPERATURE AND DATE OF FIRST SUCCESSFUL NORSING IN SCRVIVIAG INFANTS

\begin{tabular}{|c|c|c|c|}
\hline $\begin{array}{c}\text { Case } \\
\text { Number }\end{array}$ & $\begin{array}{c}\text { Birth Weight, } \\
\text { Gm. }\end{array}$ & $\begin{array}{c}\text { Day on Which } \\
\text { Temperature } \\
\text { Was First } \\
\text { Controlled }\end{array}$ & $\begin{array}{c}\text { Day of } \\
\text { First } \\
\text { Successful } \\
\text { Nursing }\end{array}$ \\
\hline $\begin{array}{r}8840 \\
8075 \\
10577 \\
8074 \\
10698 \\
11744 \\
12619 \\
11112 \\
11457 \\
11621 \\
9838 \\
12490 \\
7570 \\
6536 \\
7992 \\
7993 \\
12871 \\
8073 \\
8347 \\
11665 \\
9165 \\
10235 \\
9267 \\
12876 \\
9703 \\
8590 \\
11390 \\
7427 \\
9669 \\
10926 \\
9811 \\
8731 \\
7870 \\
11883 \\
7456 \\
7514\end{array}$ & $\begin{array}{l}1,505 \\
1,540 \\
1,640 \\
1,670 \\
1,710 \\
1,800 \\
1,800 \\
1,870 \\
1,925 \\
1,930 \\
1,940 \\
1,960 \\
1,965 \\
2,060 \\
2,000 \\
2,050 \\
2,060 \\
2,120 \\
2,135 \\
2,180 \\
2,2600 \\
2,280 \\
2,300 \\
2,300 \\
2,370 \\
2,380 \\
2,380 \\
2,400 \\
2,440 \\
2,440 \\
2,450 \\
2,455 \\
2,480 \\
2,695 \\
2,630 \\
2,815 \\
2,860\end{array}$ & $\begin{array}{r}28 \\
33 \\
30 \\
28 \\
28 \\
\frac{14}{14} \\
37 \\
21 \\
10 \\
72 \\
\frac{15}{21} \\
8 \\
8 \\
22 \\
29 \\
13 \\
8 \\
17 \\
1 \\
\frac{1}{18} \\
3 \\
\frac{3}{24} \\
5 \\
3 \\
\frac{1}{12} \\
3\end{array}$ & $\begin{array}{r}32 \\
48 \\
42 \\
71 \\
21 \\
34 \\
10 \\
19 \\
12 \\
26 \\
67 \\
18 \\
6 \\
34 \\
30 \\
28 \\
12 \\
25 \\
1 \\
10 \\
10 \\
2 \\
4 \\
6 \\
15 \\
3 \\
4 \\
5 \\
5 \\
4 \\
2 \\
2 \\
6 \\
9 \\
4 \\
3\end{array}$ \\
\hline
\end{tabular}

ADJUSTMENT OF TEMPERATURE

Incubators were not used. Instead, the babies, clad in flannel hoods and capes, were kept in blanket-lined clothes baskets containing hot water bottles. The bed temperatures were charted along with that of the baby, and held at between 85 and $90 \mathrm{~F}$. Genersich ${ }^{11}$ gives this as the optimal temperature for the premature infant's bed. None of our babies that were unable to

6. Oberwarth, E.: Pflege und Ernährung der Frühgeburten, Ergebn. d. inn. Med. u. Kinderh., 1911, 7, 191.223.

7. Birk, W.: Ueber den Nahrungsbedarf frühgeborener Kinder, conatschr. $\mathrm{K}$ inderh 1910 .

8. Ladd, M.: The Results of Substitute Feeding in Premature Infants, Arch. Pediat. 1910, 27, 416-426.

9. Salge: Einführung in die moderne Kinderheilkunde, Berlin, 1909

10. Budin, P.: The Nursling, London, 1907, p. 6.

11. Genersich: Der Einfluss der Wärme auf die Temperatur der Säug linge, Monatschr. f. Kinderh., 1910, 9, 183-199. 
maintain a normal body temperature with a bed temperature of 90 were able to do so when the bed temperature was higher. Our charts show that when the baby can maintain a normal monothermia with the aid of hot water bottles, the temperature will remain between 98 and $99 \mathrm{~F}$. without them.

The bed temperatures were taken and charted after artificial heat was discontinued, and in babies that were controlling their body temperatures the bed temperatures were uniformly between 85 and $90 \mathrm{~F}$. The temperatures of the bed of another premature baby, whose own body temperature remained between 97 and $98 \mathrm{~F}$., was constantly in the neighborhood of 80 .

Fifteen of the babies who survived had birth weights of $2 \mathrm{~kg}$. or less. On the average, they were able to control their body heat by the twenty-seventh day. Only three required hot water bottles longer than a month. One, however, needed artificial heat until he was 72 days old. None of the premature babies with a birth weight of more than $2,000 \mathrm{gm}$. required artificial heat after the first month. Twenty-one of these survived and only three needed it in the fourth week. Table 1 shows the day on which the infants began to maintain their body temperature without artificial heat.

The babies were bathed with olive oil and wiped dry with warm flannel. An aseptic nursing technic was followed, nurses and doctors washing their hands before and after contact with the infants, and wearing gauze masks if suffering with any respiratory infection, however mild. The mothers of premature infants were carefully watched, and at the first sign of coryza were made to wear masks while nursing their babies.

\section{STATISTICS OF MORTALITY FOR SURVIVORS AND NONSURVIVORS}

Of the sixty premature infants, thirty-six lived and twenty-four died, giving a gross mortality of 40 per cent. Fourteen deaths, however, or 58 per cent. of the total number of deaths, occurred on the first day. Necropsies were done on twelve of the fourteen babies,

TABLE 2.-RECORDS OF PREMATURE INFAN'IS SURVIVING SIX DAYS

\begin{tabular}{|c|c|c|c|c|}
\hline $\begin{array}{l}\text { Case } \\
\text { Number }\end{array}$ & $\begin{array}{l}\text { Birth } \\
\text { Weight, } \\
\text { Gin. }\end{array}$ & $\begin{array}{l}\text { Day } \\
\text { of } \\
\text { Death }\end{array}$ & $\begin{array}{c}\text { Probable Cause of } \\
\text { Failure }\end{array}$ & Pathology \\
\hline 11134 & 975 & 8 & $\begin{array}{l}\text { Gradual decline in body } \\
\text { temperature }\end{array}$ & No necropsy \\
\hline $838 \%$ & 1,450 & 13 & $\begin{array}{l}\text { Gradual decline in body } \\
\text { temperature }\end{array}$ & Neeropsy negative \\
\hline 7910 & 1,500 & .6 & $\begin{array}{l}\text { Gradual decline in body } \\
\text { temperature }\end{array}$ & Necropsy negative \\
\hline 7205 & 1,675 & 51 & $\begin{array}{l}\text { Par'nteral infection. } \\
\text { Mother had open pul- } \\
\text { monary tuberculosis }\end{array}$ & Necropsy negative \\
\hline 9097 & $1,8 \cdot 25$ & 43 & $\begin{array}{l}\text { Overfeeding with breast } \\
\text { milk. Babe's tolerance } \\
\text { exceeded, tomiting. Diar- } \\
\text { rhea, eczema. Mother } \\
\text { had tubereulosis }\end{array}$ & Necropsy negative \\
\hline 10168 & 2,180 & 25 & Hematemesis. Syphilis.... & No necropsy \\
\hline
\end{tabular}

and in five instances definite and adequate causes for death were found. There was extensive visceral syphilis in two cases, anencephalus in one, intraventricular hemorrhage in one, and a fractured dorsal vertebra with a lacerated spinal cord in one. Two died on the second day, one on the third, one on the fifth, and one on the sixth, all with cyanosis and a gradual decline in body temperature. One infant survived until the eighth day and another until the thirteenth day, both showing throughout a slowly falling temperature. Necropsies were done in five of the seven cases without a satisfactory cause of death being found. Of the remaining thirty-nine babies, one with syphilis died on the twenty-fifth day of hemorrhage from the stomach, and one died on the fortysecond day because his tolerance for breast milk had been overstepped. This baby apparently had taken his food well and was making a satisfactory gain in weight; but the food was increased too rapidly, the warning signal of vomiting was disregarded, diarrhea and eczema developed, and thereafter a quantity of nourishment great enough to maintain life could not be tolerated. The only other death occurred on the fifty-first day in a baby that contracted rhinitis from

TABLE 3.-RECORDS OF PRFMA'TURE INFANTS SURVIVING LESS THAN SIX DAYS

\begin{tabular}{|c|c|c|c|}
\hline $\begin{array}{c}\text { Case } \\
\text { Number }\end{array}$ & $\begin{array}{c}\text { Weight, } \\
\text { Gm. }\end{array}$ & $\begin{array}{c}\text { Day of } \\
\text { Death }\end{array}$ & Pathology \\
\hline 7457 & ..... & 1 & No necropsy \\
\hline 12900 & ..... & 1 & No necropsy \\
\hline 7996 & ..... & 1 & No necropsy \\
\hline 868 & ...... & 1 & Necropsy negative \\
\hline 7771 & 630 & 1 & No neeropsy \\
\hline 10104 & 660 & 1 & Necropsy negative \\
\hline 12895 & 700 & 1 & Necropsy negative \\
\hline 6002 & 1,060 & 3 & Necropsy negative \\
\hline 11208 & 1,185 & 1 & Hemorrhage into left lateral ventricle \\
\hline 70 & 1,210 & 1 & Anencephalus. Pulmonary hemorrhage \\
\hline 303 & 1,250 & $\overline{5}$ & Necropsy negative \\
\hline & 1,450 & 1 & Necropsy negative \\
\hline 11439 & 1,570 & 1 & Necropsy negative \\
\hline 8617 & 1,885 & 1 & $\begin{array}{l}\text { Fracture fifth dorsal vertebra, laceration of } \\
\text { spinal cord }\end{array}$ \\
\hline 34 & 1,900 & 1 & Syphilis \\
\hline & 1,910 & 1 & Syphilis \\
\hline 11490 & 2,200 & 2 & No necropsy \\
\hline 958 & 2,220 & 2 & Necropsy negative \\
\hline
\end{tabular}

some careless attendant; the temperature became irregular, the tolerance for food was lost and death ensued. The last two babies were born of mothers each of whom had an open pulmonary tuberculosis. No tuberculosis was found at the necropsies of the infants, but, as Reiche ${ }^{12}$ has pointed out, maternal tuberculosis exerts a harmful influence on the premature infant, even when the latter does not suffer from the disease.

Budin pointed out the great importance of initial chilling in producing the death of the premature infant. This most frequently occurs when the baby is born outside the hospital. Consequently, while our mortality rate is much increased by the fourteen infants who were born there and died on the first day, it suffered very little from the deaths of infants who were brought in from outside to die later. Only one such death occurred.

Table 2 shows the birth weight, the age at death and its cause in the six infants who survived longer than five days. Similar data concerning the eighteen infants who died in the first five days is contained in Table 3. It is a question as to how many of these babies were viable.

\section{PROGRESS OF SURVIVING INFANTS}

A summary of the more important information gleaned from the records of the surviving babies is presented in Table 4. It shows the progress of each baby, the ability to control temperature, to nurse, and to gain in weight. The age figures are given in days, the weights in grams. The + signs in the tenth column signify that complemental feeding was still necessary at the time of discharge, those in the eleventh, that the baby was nursing well at discharge, and those in the twelfth that at that time he was gaining satisfactorily.

The parallelism between the ability fully to control body temperature and to gain satisfactorily in weight 12. Reiche, A.: Das Wachstum der Frühgeburten in den ersten
Lebensmonaten, Ztschr, f. Kinderh., 1915, 1₹,369-401. 
is noted. .Six of the nine babies that were discharged before they were able to maintain a normal monothermia were not yet making a good gain. Because of the advantage of keeping the baby with its mother, all infants were discharged as soon as it seemed safe to discharge them. All but two babies, however, were either nursing well or gaining satisfactorily at the time of leaving the hospital. Only three infants remained in the hospital longer than two months, and two of these developed marked pallor and craniotabes in the third month. As has been pointed out by Rosenstern $^{13}$ and others, the so-called pseudorickets uniformly occurs at this period of premature life. These babies were given iron and cod liver oil and showed improvement. It would seem advisable, if not contraindicated, to start such medication as early as the second month.

\section{ABSTRACT OF DISCUSSION}

Dr. JoHn ZAHorsky, St. Louis: I have been much interested in the question of the premature infant for several years. It is much better practice to decide daily how much milk the baby shall have, by any method you choose. Write on the directions just the quantity of milk the baby should have each day, and the nurse should be instructed to give that amount in twenty-four hours. In other words, prescribe daily rations, and then try to get it to the baby. Sometimes you can do it on a four-hour schedule, and sometimes you have to feed more often to get the proper quantity. The feeding is the most important part of the care of the premature infant, not the regulation of the temperature. I always try to work on an energy quotient of 120 to 130 by the tenth day. I commence usually with only one fourth of that quantity-one fourth of 120 , or an energy quotient of about 30 the first day, and gradually increase from day to day, until we have worked up to 120 or 130 . This varies with the baby. I do not believe the

TABLE 4.-PROGRESS OF SURVIVING INFANTS IN WEIGHT, CONTROL OF TEMPERATURE, NURSING ABILITY, ETO.

\begin{tabular}{|c|c|c|c|c|c|c|c|c|c|c|c|}
\hline $\begin{array}{l}\text { Case } \\
\text { Number }\end{array}$ & $\begin{array}{l}\text { Weight } \\
\text { at } \\
\text { Birth, } \\
\text { Gm. }\end{array}$ & $\begin{array}{c}\text { Day on } \\
\text { Which } \\
\text { Babe } \\
\text { First } \\
\text { Con- } \\
\text { trolled } \\
\text { remper- } \\
\text { ature }\end{array}$ & $\begin{array}{c}\text { Day } \\
\text { of } \\
\text { First } \\
\text { Bottle } \\
\text { Feed- } \\
\text { ing }\end{array}$ & $\begin{array}{c}\text { Day } \\
\text { of } \\
\text { First } \\
\text { Breast } \\
\text { Feed- } \\
\text { ing }\end{array}$ & $\begin{array}{c}\text { Age } \\
\text { at } \\
\text { Dis- } \\
\text { charge }\end{array}$ & $\begin{array}{c}\text { Weight } \\
\text { at } \\
\text { Dis- } \\
\text { charge }\end{array}$ & $\begin{array}{l}\text { Day } \\
\text { Arti- } \\
\text { fleial } \\
\text { Heat } \\
\text { Was } \\
\text { Diseon- } \\
\text { tinued }\end{array}$ & $\begin{array}{c}\text { Comple- } \\
\text { mental } \\
\text { Feed- } \\
\text { ings } \\
\text { Neces- } \\
\text { sary } \\
\text { at Dis- } \\
\text { charge }\end{array}$ & $\begin{array}{c}\text { Nursing } \\
\text { Well } \\
\text { at } \\
\text { Dis- } \\
\text { charge }\end{array}$ & $\begin{array}{c}\text { Gaining } \\
\text { Satis- } \\
\text { facto- } \\
\text { rily at } \\
\text { Ois- } \\
\text { charge }\end{array}$ & Remarks \\
\hline 8890 & 1,505 & 28 & 32 & 32 & 38 & 1,870 & 28 & - & + & + & \\
\hline 8075 & 1,540 & 33 & 52 & 48 & 55 & 2,360 & $\rightarrow$ & + & - & + & \\
\hline 10577 & 1,640 & 30 & 一 & 42 & 49 & 2,360 & 31 & + & - & + & \\
\hline 8074 & 1,670 & 28 & - & 71 & 141 & 4,150 & 74 & + & + & + & \\
\hline 10698 & 1,710 & 28 & - & 21 & 28 & 1,860 & - & - & + & + & \\
\hline 11744 & 1,800 & - & 31 & 34 & 59 & 1,910 & - & - & 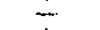 & - & Much artifleial feeding; mother did \\
\hline 12618 & 1,800 & 14 & 4 & 10 & 59 & 2,800 & 15 & - & + & + & not cooperate \\
\hline 11112 & 1,870 & 37 & 18 & 19 & 38 & 2,100 & 16 & - & + & + & \\
\hline 11457 & 1,925 & 21 & - & 12 & 28 & 2,640 & - & + & - & + & \\
\hline 11621 & 1,930 & 10 & 10 & 26 & 39 & 1,830 & 27 & - & + & + & \\
\hline 9838 & 1,940 & 72 & 67 & - & 168 & 3,770 & - & - & + & + & Psendorickets \\
\hline 12490 & 1,960 & $\overline{-}$ & 18 & 18 & $3:$ & 2,120 & - & 一 & + & - & Temp. not controlled; weight gain \\
\hline 7570 & 1,965 & 15 & & 6 & 19 & 1,950 & - & + & - & + & slight \\
\hline 6536 & 2,000 & 21 & 34 & & 151 & 4,350 & - & - & - & + & Pseudorickets \\
\hline 7992 & 2,000 & 8 & 29 & 30 & 39 & 2,280 & - & + & $\ldots$ & $\dot{+}$ & \\
\hline 7993 & 2,050 & 8 & 29 & 28 & 38 & 2,380 & - & + & - & + & \\
\hline 12871 & 2,060 & 22 & $=$ & 12 & 31 & 2,460 & - & + & - & + & \\
\hline 8073 & 2,120 & 28 & 25 & 25 & 38 & 2,540 & - & + & - & + & \\
\hline $834 \bar{i}$ & 2,135 & 13 & - & 1 & 24 & 2,030 & - & + & + & $\div$ & \\
\hline 11665 & 2,180 & 8 & - & 10 & 13 & 2,520 & - & + & $\therefore$ & $\dot{t}$ & \\
\hline 9165 & 2,260 & 17 & - & 10 & 25 & 2,220 & - & + & - & + & \\
\hline 10235 & 2,280 & - & - & 2 & 15 & 2,210 & - & - & + & + & \\
\hline 9267 & 2,300 & 1 & - & 4 & 11 & 2,060 & - & - & + & - & Temp. slightly subnormal; weight \\
\hline 12876 & 2,300 & $\overline{70}$ & - & 6 & 10 & 2,290 & $\overline{10}$ & + & + & + & stationary \\
\hline 9703 & 2,370 & 18 & - & 15 & 26 & 2,630 & 18 & $\therefore$ & + & + & \\
\hline 8590 & 2,380 & - & - & 3 & 10 & 2,220 & - & - & + & - & Temp. not controlled; weight sta- \\
\hline 11390 & 2,400 & 3 & - & 4 & 11 & 2,310 & - & - & + & + & tionary \\
\hline 7427 & 2,440 & & . & 5 & 11 & 2,160 & - & - & + & 一 & Temperature 97 to $98 \mathrm{~F}$ \\
\hline 9619 & 2,440 & 24 & - & 5 & 33 & 2,630 & - & + & + & + & \\
\hline $109: 6$ & 2,450 & $\overline{5}$ & - & 4 & 12 & 2,430 & - & - & + & + & Temperature above $97 \mathrm{~F}$. \\
\hline $\begin{array}{l}9811 \\
8731\end{array}$ & $\begin{array}{l}2,455 \\
2,480\end{array}$ & $\stackrel{5}{-}$ & - & $\begin{array}{l}2 \\
2\end{array}$ & $\begin{array}{l}10 \\
12\end{array}$ & $\begin{array}{l}2,430 \\
2,470\end{array}$ & - & $\overline{-}$ & + & $\begin{array}{l}+ \\
+\end{array}$ & \\
\hline 7870 & 2,595 & 3 & 5 & 6 & 10 & 2,330 & - & - & + & + & \\
\hline 11883 & 2,630 & - & - & 9 & 11 & 2,580 & - & + & - & - & \\
\hline 7456 & $\begin{array}{l}2,815 \\
2,860\end{array}$ & $\begin{array}{r}12 \\
3\end{array}$ & 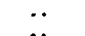 & $\begin{array}{l}4 \\
3\end{array}$ & $\begin{array}{c}16 \\
9\end{array}$ & 2,600 & 二 & $=$ & + & + & \\
\hline 614 & 2,000 & 。 & $\cdots$ & 3 & $\boldsymbol{y}$ & 2,630 & 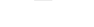 & 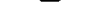 & $T$ & + & \\
\hline
\end{tabular}

\section{CONCLUSION}

It is found that of sixty infants fed breast milk on the four-hour interval, by tube when necessary, kept sufficiently warm and protected against infection, thirty-six lived and twenty-four died, a gross mortality of 40 per cent. When, however, one deducts the fourteen deaths occurring on the first day, the mortality rate of the remaining forty-six cases falls to 22 per cent.

The most favorable view of the treatment employed is gained if only the forty-two babies living longer than five days are considered. Among these, including two who by better judgment and technic could have been saved, there were six deaths, giving a mortality of 14 per cent. ${ }^{14}$

13. Rosenstern, I.: Hunger im Säuglingsalter und Ernährungstechnik, Deutsch. med. Wchnschr., 1912, 38, 1834-1839.

14. In addition to the references already given, the following will be found of interest:

La Fetra, L. E.: The Hospital Care of Premature Infants, Arch.

Pediat., 1916, 33, 352-356. interval makes any material difference. What does matter is that you get into the baby the required quantity of food. The symptom of cyanosis which comes frequently is due to apnea, and may frequently be due to exhaustion. There is not enough energy to keep up respiratory efforts. It is necessary to get sufficient food into the baby, regardless of the intervals between feedings.

As to the question of temperature, I think it is a little high in this paper. With a small baby, under 2,000 gm., it is necessary to commence with a temperature of from 85 to 90 ; you want to gradually reduce this temperature, because slightly overheating a baby often produces cyanosis, and not only that, it seems to diminish the internal power of oxidation. I like to keep the baby as cool as possible, and still maintain a bodily temperature of at least 98 degrees. The most important symptom to combat with a premature baby is apnea. Cyanosis is liable to occur in any feeble infant. To prevent this, in the first place I think a proper fat supply should be maintained. It might occur, of course, from overfeeding or from infection. These cases are always given some respiratory stimulant, in addition to oxygen to dispel the cyanosis, usually caffein or smail quantities of tea. I 
think caffein is very helpful in stimulating the respiratory centers.

Dr. IsAAC A. ABT, Chicago: I presume four-hour feedings will work out in a certain number of cases, even with premature babies. It seems to me that if a premature baby is fed only once in four hours, it will have to take a larger quantity at each feeding than if it were nursed every two or three hours. A baby's stomach at this time is naturally limited in size, and it appears to me that one gets better results if the baby is fed small quantities at relatively frequent intervals. I do not believe that the four-hour feeding plan should become a dogma. I see men who believe it is their whole business to have a baby fed only once in four hours, and if they think you order feedings every three hours they stand aghast. After all, we are dealing with individuals, and while a certain number of prematures may do well on fonr-hour feedings, I believe most prematures should be fed more frequently-possibly every two or three hours. Budin laid down the principles in his little book that prematures suffer from two great troubles-one, difficulty in maintaining body temperature, and secondly, most of them fail to prosper because of insufficient food. It seems to me, in order to supply the amount of food they need, they should be fed small quantities at frequent intervals. Dr. Taylor has already made the point that these babies should receive breast milk. This should be emphasized over and over again. Premature babies who are fed malted milk or condensed milk, or even cow's milk diluted, are extremely difficult to raise. I believe no real success can be obtained with these infants unless they receive breast milk.

Dr. Lawrence T. Royster, Norfolk, Va.: Most of the work I have done with prematures has been in private practice, outside of hospitals-a number were in outlying country districts where facilities were few and nurses often not available. I have met with some degree of success. As Dr. Abt has said, we must consider the individuality of the patient. The stomach of the premature infant varies just as much as the fullterm infant's stomach does. Therefore, the ratio between the quantity given and the size of the stomach must be studied individually. I do not believe I ever fed a premature infant at four-hour intervals. From the standpoint of a private practitioner, outside of hospitals, I do not believe that it is feasible without a stomach tube. I do not use a stomach tube frequently because $I$ have not often a person near who is qualified to do it. Of course, where there is no nursing power, that is essential. My most frequent interval for the first few days is two hours, and 1 to 2 drams is all that we can get in. I have tried a larger amount and a longer interval, but found that the babies did not thrive. Breast milk in these cases is almost a sine qua non. Some of the smallest premature babies I have ever reared never had a drop of breast milk. My plan in these cases has been to start with whey. Some will criticize this. However, I am talking from experience. Whey, diluted or whole, according to the patients' ability to assimilate, is a very good substitute for tiding over this time. After they take this, I then go to a straight modification of cow's milk.

Prematurity, of course, is a terrible handicap for a baby. A great many premature babies come as a result of various "accouchement force" methods which may be necessary on account of the condition of the mother. I do not wish to enter into a discussion of cesarean section, etc., but we have found that premature babies who have come as a result of cesarean section have given us an easier task than those brought into the world by rapid dilatation, and then the necessitated handling of the child with forceps.

Dr. Frank C. NefF, Kansas City, Mo.: I think we should not overlook one thing Dr. Taylor has mentioned, and that is the aseptic handling of these babies. As you all know, premature babies are a matter of great curiosity. I have found it very difficult to keep visitors away, and it can easily be seen how infection can occur. As to what Dr. Royster said as to feeding these babies with a tube, I do not think it is particularly difficult. On several occasions I have shown the mother how to use the tube, and she has done it successfully. I want to ask Dr. Taylor one thing: At what period does a gain in weight usually begin?
Dr. Jane M. Ketcham, Indianapolis: Premature babies should not be overhandled. With them I use a stomach tube every four hours for the first week. In the effort to get the child to nurse it is often handled too long and becomes chilled, and thus you defeat your own end. The stomach tube is a great advantage. After the child has the strength to nurse it is better for it to make the effort. It is an advantage to have the baby weighed before and after every feeding, so that we may know how much it is receiving. The symptom of vomiting is of the greatest importance and must not be overlooked, because when a child once begins to vomit it is impossible to know how much food it is retaining or for it to retain sufficient. The symptom of cyanosis can best be treated by oxygen, hypodermically, or by 5 to 20 per cent. glucose solution. The body fluids must be kept up at all costs. This is equally as important as maintaining an equable temperature. Great.c.re must be taken not to ove hhandle a child.

Dr. Jules M. Brady, St. Louis: When this four-hour interval was first called to my attention in 1910, I did not see how it was possible to get sufficient nourishment into a premature infant in this way. It is like everything else-we have to try it to be convinced. Having had experience in numerous hospital cases, I have been convinced. There is one symptom that will throw a scare into one, and that is vomiting. When this appears, I think the chances of bringing through the premature are diminished. Feeding breast milk at fourhour intervals I think is the best method to prevent the appearance of this vomiting, which is so dangerous to the premature infant. If you cannot get breast milk, as sometimes occurs, I believe it is necessary to feed at shorter intervals.

Dr. JaY I. Durand, Seattle: Hunger is a detriment to a baby, and keeping babies on a starvation diet has, I think, done more damage than any other one fault in our infant feeding. Barley water for more than a twenty-four-hour period is never necessary in gastro-intestinal disturbances, and no variation of the normal feeding need be made in parenteral disturbances except the reduction, which no child voluntarily makes by refusing part of the nursing. The younger the baby, the greater is the danger from hunger. In prematures, the four-hour interval is the best. I had one premature of 2 pounds 3 ounces, which gained beautifully on four-hour feeding intervals, but you must see to it that the infant gets enough to cover its caloric needs. If the baby does not take enough from the breast, bottle, dropper or Breck's feeder, gavage must be used.

Dr. Edgar J. Huenekens, Minneapolis: I am especially interested in the rickets or pseudorickets that these premature infants develop. In a recent series of cases, I found 92 per cent. showed evidences of rickets. I believe this depends on a shortage of calcium in the infant's organism. Basing my treatment on the work Schloss has done in the treatment of rickets in breast-fed infants, I give these babies tricalcium phosphate with cod liver oil. I use a 10 per cent. mixture of tricalcium phosphate in an emulsion of cod liver oil. The results seem to warrant further trial.

Dr. Harry Lowenburg, Philadelphia: Several years ago in discussing this subject, I took the stand that we should treat the individual. It is very dangerous to become dogmatic about anything in medicine, especially infant feeding. Another thing comes to my mind, and that is that in passing the tube to feed these infants, it is much easier in my experience to pass it through the nose. I have also used a 5 per cent. sterile solution of glucose injected through the anterior fontanel directly into the longitudinal sinus, and I feel that it has done some good. Obstetricians are the chief offenders in destroying the maternal milk supply. I think that they should be told that either they should learn the principles of infant feeding, or leave the premature infant alone, as well as other infants.

Dr. F. C. WA HRER Fort Madison, Iowa: Prematurity is the exception, and when we are making rules, let us not forget the exceptions. When you make a rule for all, you must use the rule and the exception; in some cases the rule may apply, in some the exception-and in some others the exception to the exception. Suppose a child is born four weeks too soon. At the end of two months is it 4 weeks old or 2 months? Does it still partake of the condition in utero pertaining 
before its birth? If it does, then there is some good sense in feeding a child at four-hour intervals, which would not have been fed anything if it had remained those four extra weeks in utero. I think it is a question whether it even needs to be fed as often as Dr. Taylor suggests. But since we cannot make rules for every child, we must adopt separate rules for each child, as I am sure that some premature children must be fed oftener than other equally premature children.

Dr. Abraham Jacobi, New York: I believe, as has been said, that every case has to be treated individually. You have to use your brains. I believe every one who has spoken was correct-correct in his own case-but only in his own case. We should study the babies and study the babies' mothers, and we will be better off. I am not in a position to say that your babies and the other doctors' babies will do well on the same treatment. That is impossible.

Dr. RoOD TAYLOR, Rochester, Minn.: I went over the charts of Dr. Sedgwick's patients at the University of Minnesota Hospital. I was so much interested in what I found on those charts that I secured Dr. Sedgwick's permission to report what I found. All those babies happened to be fed on the four-hour interval. All the prematures did well on it. There is this to be said for using a standard interval-it helps one to gage when the tolerance of that particular baby is being overtaxed. Dr. Zahorsky mentioned the importance or nonimportance of the baby's maintaining its own temperature. There were nine patients in this series who were not maintaining temperatures very well. Of these, six were not gaining. As regards the small amounts of breast milk taken at a time, I think the reason most often is not the size of the baby's stomach, but the inability of the premature baby to nurse well, whether it is due to lack of the sucking reflex or what not. The stomach of the new-born is much more active than that of the adult, and the stomach of the premature infant is much more active than that of the new-born, as the latter is more active than the stomach of the adult. Although no work has been done on the subject, I believe the stomach of the premature infant empties itself more rapidly than the stomach of the full-term infant.

We do not see in the hospital, nor have I seen outside of it, women with premature babies, who did not have breast milk. Some of these women were very sick, and some septic, but if we wait long enough there will be breast milk. Without exception, we have always had breast milk for the premature baby-that is, provided the mother lived. In regard to the use of the nasal tube, I have had no difficulty in passing the tube through the mouth, and I believe it is generally considered safer to pass through the mouth because of the danger of passing it in to the cranium. These babies gained weight very slowly, but came along all right in the end.

Health and Ethics.-The basis of ethics, then, is the health of the community. That fact we know, but we do not know it fully; we have not exhausted its riches. We have improved sanitation; we have improved the conditions of labor both as regards positive risks and the character of buildings. In these things the best and the most efficient have proved identical; so far economics has supported ethics. But economic production and efficiency are liable to be dangerous allies; we must not be led astray by a faise ideal of industrial growth. Nor must we suppose that our duty ends with the physical welfare of the population. Already there are ample proofs that we shall be carried from external to internal conditions, from individual to racial questions, from health of body to health of mind. And by health of mind must be understood much more than crude questions of insanity, crime and feeblemindedness. The human race tends to emphasize more and more its own peculiar feature; its consciousness becomes more acute and more comprehensive; it cannot, like the animal, merely eat and drink and sleep; while we teach prudence and thrift we are developing, if I may so put it, the organs of worry and anxiety. This too will have its pathology, personal and social, an evil which is far from imaginary and has its witness in much of the present unrest. All these things must be included in our idea of the "public health" and we must organize for nothing less comprehensive.-G. S. Brett, Pablic Health Journal, August, 1918.

\section{A FURTHER CONSIDERATION OF COMPLEMENT FIXATION IN TUBERCULOSIS *}

\author{
V. H. MOON, M.Sc., M.D. \\ INDIANAPOLIS
}

The demonstration of antibodies in the circulating blood by complement fixation was first accomplished by Bordet and Gengou ${ }^{1}$ and its application was made to tuberculosis by them several years before Wassermann and Bruck successfully applied the test in syphilis. If medical men should desire a less cumbersome term than the complement fixation test for tuberculosis it seems they could not do better than to term it simply "the Bordet test." The term has the advantage of brevity. It is historically accurate, and would fittingly perpetuate the name of the distinguished French investigator who first demonstrated the part played by complement in immune reactions-a discovery by which his German contemporaries were not slow to profit.

Wassermann and Bruck $^{2}$ made experiments with complement fixation in tuberculosis before they developed the test for syphilis, and subsequently Citron ${ }^{3}$ made similar experiments. In these earlier tests, Koch's "old tuberculin" was used as antigen. For several years no marked progress was made in applying the test to the diagnosis of tuberculosis, possibly because of variation in the results in the earlier tests. Within recent years numerous articles have appeared reporting favorable results in the application of the test to extensive series of cases. The most significant feature of these reports is that, while there are differences in data and percentages due evidently to the different methods and reagents used, there is agreement that complement fixation under proper conditions gives positive results in the majority of cases of active tuberculosis. The laboratory technic employed in this test is the same in principle and in main details as in complement fixation applied to the diagnosis of syphilis. As in that test there have been many variations in the technic and in the reagents employed, and as would be expected, the results have also varied. The widest variation occurs in the preparation used as antigen, but each of the antigens used successfully has consisted of some preparation of tubercle bacilli. The reaction is one of biologic specificity depending on the presence in the patient's serum of free antibodies specific to tubercle bacilli. In this particular, the situation differs from that in syphilitic infection.

In reviewing the reports of this test, Miller ${ }^{4}$ has classified the antigens into the following groups:

Group I. Antigens consisting of suspensions of whole or ground up tubercle bacilli.

Group II. Antigens which may be classed as tuberculins.

Group III. Antigens consisting of extracts or derivatives of tubercle bacilli.

Group IV. Preparations or extracts of normal and tuberculous organs, as lungs, lymph nodes, spleen, etc.

\footnotetext{
* From the Department of Pathology, Indiana University School of Medicine.

* Read before the Section on Pathology and Physiology at the Sixty. Ninth Annual Session of the American Medical Association, Chicago, une, 1918

1. Bordet and Gengou: Compt, rend. Acad. de sc., 1903, 137, 2. Wassermann and Bruck: Deutsch. Med. Wchnschr., 1906, 32. 49.

3. Citron: Berl. klin. Wehnschr, 1907, 3, 1135.

4. Miller: Jour. Lab. and Clin. Med., 1916, 1, 816.
} 